\title{
EXPLORING COMPETING VALUE FRAMEWORK ON HOW PROFESSIONALS' JOB SATISFACTION AFFECTED BY ORGANIZATION CULTURE
}

\author{
Aransyah Muhammad Fikry ${ }^{1 *}$, Widyanto Eko Adi ${ }^{2}$, Hetami Aditya Arie ${ }^{1}$ \\ ${ }^{1}$ Department of Business Administration, Mulawarman University, Samarinda, Indonesia \\ ${ }^{2}$ Department of Accounting, Politeknik Negeri Samarinda, Indonesia \\ *E-mail: fikry.aransyah@gmail.com
}

\begin{abstract}
This research aims to evaluate the ideal culture that determines the satisfaction of employees. The level of satisfaction at the job should be based on recruiting more professionals because it is vital to attract and retain professionals. Nevertheless, the organizational culture was addressed as a significant factor affecting qualified professionals' job satisfaction. Thirty empirical papers from the period from 2014 to 2019 were chosen for this research. There are many types of research being conducted about job satisfaction, but there is limited research being conducted to explore professionals' job satisfaction. It reviews competing value frameworks studies and theories on organizational culture toward job satisfaction and also the concepts of clan, market, clan, adhocracy, market, hierarchy, and knowledge sharing cultures. The result of this literature study found that the impact of the clan, adhocracy, and knowledge sharing culture significantly influences the professional's job satisfaction.
\end{abstract}

\section{KEY WORDS}

Job satisfaction, organizational culture, competing value framework.

The experience of the employees is essential because of the shift of the organization to networking and team structures. Therefore, successful businesses with great empathy, cultivate cultures that give priority to people (Ferres, 2015). Employee dissatisfaction would lead to high turnover and low productivity (Mayhew, 2017). Academics and managers, therefore, focus their interests on human resources management studies related to employee satisfaction.

Organizational culture is vital to promote corporate strategies, visions, and goals. Therefore, existing organizational culture may need to change to promote the progress and success of the organization. This has affected the long-term sustainability of being a professional in the existing corporate culture of companies, such as excessive regulations and tight deadlines (Hermanson, Houston, Stefaniak, and Wilkins, 2016). Furthermore, the competitive culture of firms that require professionals to manage multiple commitments, customers, and quality assurance, has arisen from a questionable problem regarding employee satisfaction (Lee, 2018). In the context of organizational culture, past researchers have adopted various models like Hofstede's (Soltanizadeh and Sanaei, 2015) and competing value framework (Ahamed \& Mahmood, 2015; Taskiran, Cetin, Ozdemirci, Aksu \& Istoriti, 2017).

Most previous studies relating to the organizing culture of services, such as hospitals (Janjua, Ahmad, and Afzal, 2014), banks (Beliasa, Kousteliosa, Vairaktarakisb \& Sdrolias, 2015) and hotels (Oz, Kaya, \& Ciftci, 2015; Zahid, Shaikh \& Zehra, 2017). However, the role of accountability is becoming demanding in supporting strong public and private sector economic growth (Moyes, 2008). For the limited attention given by past researchers, accounting companies are therefore chosen to bridge the gap in this research. In Western countries like Turkey (Balier \& Oscan, 2017) and the United Kingdom (Fair \& Wright, 2016), the links between organizational cultures and employee satisfaction have been examined but are restricted among Asian contexts (Chan, Wong \& Wok, 2017).

Past researchers have discovered that the culture of knowledge sharing has favored job satisfaction in accounting companies. The sharing of information has made it easy for all 
(Trivellas, Akrivouli, Tsifora \& Tsoutsa, 2015; Yunus, Yunus, Rahman, Aziz, Noranee \& Razak, 2014). However, knowledge sharing culture and the context of competing values are often studied on job satisfaction separately. This study will integrate a culture of knowledge sharing into a competing value framework to address a link between culture and satisfaction.

\section{METHODS OF RESEARCH}

Every article of primary source material in the research area of job satisfaction could not be sampled. This research incorporates a range of characteristics of the research mentioned above but differs in several important respects. The period from 2014 to 2019 was chosen for this research. This analysis is limited by the number of publications that can be thoroughly examined. During a two-blind peer review, long-term and well-respected journals have been selected that are international and promote quality work. Thirty journals have been selected to identify the 'best' job satisfaction and organizational culture research and widely recognized as top journals in the field. The authors used a traditional literature review for our review research on organizational culture and their impact on job satisfaction. Authors focus only on empirical papers. Exclude conceptual documents, real literature reviews, or papers where the organizational culture and its impact on job satisfaction was a peripheral component of the research.

\section{RESULTS AND DISCUSSION}

Cameron and Quinn first developed the Competing Value Framework following their study into organizational performance metrics (Cameron \& Quinn, 2006). The theory was reorganized into two dimensions (flexible-control and internal-external), where the four quadrants of competing for organizational values were studied on organizational effectiveness research (Cameron, 2011). Competing Value Framework developed four models and classified them into four types of Organizational Culture, which are clan, adhocracy, market, and hierarchy (Cameron \& Quinn, 2006, p.28). Each model is appropriate for its classified culture (Karimi \& Kadir, 2012).

\begin{tabular}{ll|l}
\multicolumn{2}{c}{$\begin{array}{l}\text { Clan Culture } \\
\text { (human relation) }\end{array}$} & $\begin{array}{l}\text { FLEXIBILITY } \\
\text { (open system) } \\
\text { Means: Flexibility and readiness }\end{array}$ \\
\cline { 2 - 3 } INTERNAL & $\begin{array}{l}\text { Means: cohesion and moral } \\
\text { Hierarchy Culture } \\
\text { (internal process) } \\
\text { Means: Stability and control }\end{array}$ & $\begin{array}{l}\text { Market culture } \\
\text { (rational goal) } \\
\text { Means: Productivity and efficiency }\end{array}$ \\
& \multicolumn{2}{|c|}{ CONTROL }
\end{tabular}

Figure 1 - Insight into the overall framework

Competing Value Framework is also studying the four Organizational Cultures with the most critical organizational efficacy variables, and job satisfaction is critical (Yu \& Wu, 2009). Lund (2003) first established the relationship between Organizational Culture and job satisfaction. Also, past studies have studied that businesses with market and hierarchy culture have been less satisfied with job satisfaction relative to the clan and adhocracy (Zeleke \& Beyene, 2015; Ashraf \& Rezaie, 2015; Ozturk, Hancer \& Wang, 2014). Figure 1 shows the implications of each society. An organization has a prevailing cultural style (Quinn \& Cameron, 1983). Competing Value Framework is recognized in recent empirical studies for researching organizational culture (Table 1).

The culture of knowledge sharing is also a substantial factor in job satisfaction. According to Rehman, Mahmood, Salleh, and Amin (2014), the absence of a culture of knowledge sharing increases employee stress and thus leads to job unhappiness. Besides, knowledge sharing culture allows an employee to learn and improve oneself. The culture of knowledge sharing promotes the exchange of knowledge between individuals. As a result, 
knowledge sharing culture has a positive impact on job satisfaction in service research (Kuzu \& Ozilhan 2014). Clan culture, however, concerns sharing beliefs, emotions, and trust in the workplace among employees (Chan, 1997). On the other hand, the culture of knowledge sharing emphasizes information and experience sharing (Marouf, 2015). The knowledgesharing process allows employees a smooth and efficient internal flow in accounting information, audit engagement experience, customer information, and auditing process to be shared at a lower cost, according to Chow, Ho, and Vera-Murioz (2008), since it reduces work duplication and enhances quality control.

Table 1 - Past Studies Using Competing Value Framework in Recent Year

\begin{tabular}{|c|c|c|}
\hline Author & Research Area & Research Purpose \\
\hline Irfan and Marzuki (2018) & Education & $\begin{array}{l}\text { To examine the connection between organizational culture, } \\
\text { work motivation, and work for academic employees. }\end{array}$ \\
\hline $\begin{array}{l}\text { Ogbeibu, Senadjki, and } \\
\text { Gaskin (2018) }\end{array}$ & $\begin{array}{l}\text { Manufacturing } \\
\text { Industry }\end{array}$ & $\begin{array}{l}\text { To study the effect of organizational culture on employee } \\
\text { creativity by taking into consideration the goodness of the } \\
\text { leader as a mediating factor. }\end{array}$ \\
\hline $\begin{array}{l}\text { Chatterjee, Pereira, and } \\
\text { Bates (2018) }\end{array}$ & $\begin{array}{l}\text { Learning Transfer } \\
\text { Organization }\end{array}$ & $\begin{array}{l}\text { Examine how the Learning Transfer Organization is influenced } \\
\text { by organizational culture under employee perceptions. }\end{array}$ \\
\hline $\begin{array}{l}\text { Felipe, Roldan, and } \\
\text { LealRodriguez (2017) }\end{array}$ & Innovative Sector & $\begin{array}{l}\text { To study the impact on organizational agility of various cultural } \\
\text { values. }\end{array}$ \\
\hline Cherchem (2017) & Family SME & $\begin{array}{l}\text { Business Cultures ideal for the management of family } \\
\text { businesses and their long-term market focus. }\end{array}$ \\
\hline
\end{tabular}

Source: Developed for research.

Clan culture has strongly and positively linked to healthcare work satisfaction (Dadgar, Barahoue, Mohammadi, Ebrahimi \& Ganjali 2013). Research on clan culture also demonstrated a significant positive relation to job satisfaction (Koutroumanis, Alexakis \& Dastoor 2015; Badawy, Kamel \& Magdy 2016; Yaoprukcha \& Kardkarnkla 2014) and was considered to be an extended family (Heritage, Pollock \& Roberts 2014).

Table 2 - Definitions of Job Satisfaction

\begin{tabular}{|c|c|}
\hline Authors & Definitions of Job Satisfaction \\
\hline Pichler and Wallace (2009) & $\begin{array}{l}\text { Job satisfaction refers to the emotional status within an employee as } \\
\text { integration to the extent of job appraisal and related job values. }\end{array}$ \\
\hline Aziri (2011) & $\begin{array}{l}\text { Job satisfaction refers to employees' feelings and attitudes toward their job, } \\
\text { which would be affected by their needs, desires, and experiences. }\end{array}$ \\
\hline $\begin{array}{l}\text { Ravari, Mirzaei, Kazemi, and } \\
\text { Jamalizadeh (2012) }\end{array}$ & $\begin{array}{l}\text { Job satisfaction is the perceptions of employees toward the environment, } \\
\text { relationship, opportunities, and salary paid in an organization. }\end{array}$ \\
\hline Sypniewska (2013) & $\begin{array}{l}\text { Job satisfaction is the emotional perceptions and reactions affecting the work } \\
\text { quality. }\end{array}$ \\
\hline $\begin{array}{l}\text { Thiagaraj and Thangaswamy } \\
\text { (2017) }\end{array}$ & Job satisfaction is agreed and satisfied with the current job status \\
\hline
\end{tabular}

Source: Developed for the research.

Table 2 shows the definitions of job satisfaction from various past studies. An organization's culture has been an essential indicator of job satisfaction. According to Sinaga, Siburian, and Lubis (2018), the satisfaction of employment could be driven by academic industry organizational culture. Besides, organizational culture has an extensive connection with work satisfaction in the field of engineering (Chipunza \& Malo 2017) and academics (Martínez-León, Olmedo-Cifuentes \& Ramón-Llorens 2018). Besides, a supporting culture reflects the positive outcome of job satisfaction between professional public relations (Meng \& Berger, 2019) and hospitality industries (Dirisu et al., 2018).

Dadgar, Barahoue, Mohammadi, Ebrahimi, and Ganjali (2013) emphasized that the positive result in clan culture is due to the comfortable working environment. The opportunity to participate in the decision-making process has generated a sense of belonging. Similarly, 
the Badawy, Kamel, and Magdy study (2016) indicated that clan culture could promote employee involvement and group discussions. Clan culture is thus the most important cultural factor because it can build a more positive working environment.

Professionals working under clan culture can find fewer arguments between colleagues as mutually agreed decisions can be reached through discussions that improve cohesivity, confidence, and participation levels (Hui et al., 2019). The clan culture that attaches great importance to personal values and respect for individuals is the strongest predictor of satisfaction at work as everyone has their dignity and is born with the right to be respected.

In this study, clan culture refers to a culture that focuses on people where the professionals are involved in teamwork to achieve corporate success. As is established in the non-manufacturing sector, it is preferable to encourage collaboration within the environment, because clan culture enables long-term, continuous improvement that is essential in the accounting industry as teamwork strives to achieve a high level of job satisfaction (Hui et al., 2019).

The Ashraf and Rezaie study (2015) shows positive relationships between organizations implementing the culture of adhocracy and employee satisfaction because it provides high flexibility and emphasizes work creativity. According to Shurbagi and Zahari (2014), Aldhuwaihi and Shee (2015), the culture of adhocracy could have a positive effect on job satisfaction. Ozturk, Hancer, and Wang (2014) have shown that the negative correlation between adhocracy and turnover.

Hui et al (2019) showed that the resulting relationship was positive in job satisfaction because of the innovative and creative culture (Ashraf \& Rezaie, 2015). Also, an innovative culture can inspire employees to overcome problems and openly encourage new thinking that inspires employee satisfaction (Goryachev 2018). Professionals were therefore predicted to prefer a corporate adhocracy culture as they could quickly reconfigure and improve adaptability in response to changing business trends and rules and regulations. As most respondents are under the age of 31 and millennials, flexibility is highly requested (The 2017 Deloitte Millennial Survey, 2017; Nale, 2018). A flexible work arrangement could thus reduce job dissatisfaction as professionals achieve a better balance between work and life. As a result, job satisfaction increases with the implementation of a flexible and innovative culture.

The adhocracy culture encourages employees from the accounting sector's framework to pursue an innovative approach in introducing and implementing the latest accounting systems, such as software from AutoCount and finance at work. Moreover, the culture of cloud-based accounting companies that can cope with rapid business changes could lead professionals to feel excited about and motivated to work.

Market culture has influenced the involvement of professionals at the business school, Brazil, negatively and significantly from Reis, Trullen, and Story's (2016) research. From previous studies, employees with a market culture have a considerable negative impact on job satisfaction (Din \& Ghetany, 2016) and employment motivation (Panagiotis, Alexandros \& George, 2014). However, Shurbagi (2015) study shows that market culture has a positive correlation with employee satisfaction.

Besides, a new study indicated that there is a positive impact on Portuguese non-profit organizations in the healthcare industry (Pinho, Rodrigues \& Dibb, 2014). However, the relationship between faculty members in Punjab's medical center does not reflect significant results (Khurshid \& Awan, 2017). Also, Shurbagi (2015) argued that recognition of work was the main contributor to an employee working in a competitive position. Although employees may be satisfied with the job, high performance at work is not necessary. Therefore, the market culture concerning the success of work and performance is not the predictor of job satisfaction. Moreover, the achievement of goals emphasizes reliable business performance and does not reflect the employee's level of happiness (Moyes, 2008).

It could be predicted that the market culture, which drives business goals focused on work performance, does not have a relationship with a satisfaction level of professionals due to the agreeableness cognition to serve the company as their responsibilities. Thus, the market culture has no significant relationship to job satisfaction (Hui et al. 2019). Khurshid 
and Awan (2017), however, argued that there is no significant relationship between the culture of the market and job creation. Based on this research, market culture refers to a culture of results in which employees are struggling to compete with employees for shortterm purposes. In the accounting firm, professionals often have highly competitive working environments with pressure and dissatisfaction with their jobs.

The hierarchical culture about the study of Santos, Rivera, Pinto, and Oliveira (2018) is significantly related to job satisfaction in the banking sector. Besides, the culture of hierarchy has a significant impact on employee turnover, as shown in the Kwakye study (2018). Previous research has also shown that the culture of hierarchy has significant and adverse effects on job satisfaction (Zeleke \& Beyene, 2015) and commitment to work (Monga, Monga, Mahajan \& Monga, 2015). Moreover, Samuel (2015) has shown that the culture of hierarchy and work stress have a significant and positive connection. However, Rastegar and Aghayan (2012) contributed to the contradictory result by demonstrating the lack of an essential correlation between the culture of hierarchy and job satisfaction.

Accounting companies generally perceive long working hours, strict deadlines, and strict regulations. The fact is that accountants must comply with professional standards in order to ensure that their rights are appropriately protected (Rakowska, Valdes-Conca \& Juana Espinosa, 2018). Therefore, rigid work practices and tight deadlines are prevalent in accountancy companies, known as a hierarchy in this study, and are unavoidable cultures. This culture is therefore taken for granted in accounting firms, and the professionals can be assumed to adapt to a highly formalizing working environment and to have a minimal effect on job satisfaction in the form of a hierarchy culture (Heritage, Pollock, and Roberts, 2014).

Besides, the promotion in an accounting company is widely accepted based on paper qualifications such as ACCA, MIA, and CIMA. By holding professional qualifications in accounting, they are most likely to receive higher pay through higher rankings compared to younger employees. By receiving higher compensation, professionals can reasonably experience increased workload and employment stress because of more extensive employment ranges and greater responsibility (Hui et al., 2019). According to the research findings from Zotorvie, Kudo, and Adade (2017), the main factor for determining employee satisfaction and turnover intentions among professionals is the basic salary. Professionals can be called compensation satisfactory, where they are more concerned with financial rewards rather than the hierarchical culture they must become accustomed to. The absence of an essential link between the culture of hierarchy and job satisfaction is thus demonstrated.

From an accounting firm's perspective, a hierarchical culture requires a professional to perform various tasks on low costs within a limited period, thereby creating a source of work stress and thus resulting in dissatisfaction. Also, most previous studies indicate a significant and negative relationship between the culture of hierarchy and job satisfaction.

Knowledge Sharing Culture is the main element in the satisfaction of jobs in most business environments, according to the studies by Kianto, Vanhala, and Heilmann (2016). Besides, the positive and significant effects of Knowledge Sharing Culture have been demonstrated by Raisy and Forutan (2017), Tarigh and Nezhad (2016), and Saeed (2016). The emergence of technological solutions in accounting companies such as the Accounting Information System has replaced traditional accounting methods.

Hui et al (2019) suggested that accountants prefer to share knowledge and experience in the workplace. In general, sharing knowledge is a critical component for the satisfaction of jobs under the knowledge management process (Kianto, Vanhala \& Heilmann 2016). As an accounting firm is a kind of professionals provide their customers with services based on their expertise and qualifications. An accounting firm is thus known as a knowledge-intensive company, in which the sharing of knowledge may add value to the services provided concerning efficiency, quality of assurance, and efficiency (Janus, 2016). The knowledgesharing culture, which promotes the sharing of experiences, therefore allows professionals to gain better analytical qualifications, problem-solving skills, and other employment-related skills and thus improves their self-realization, which can improve job meaning and job satisfaction. 
Thus, knowledge sharing is intended to make it easier for employees to learn the IT solution and other audit and accounting information. It saves time and effort as Knowledge Sharing Culture prevents duplication of work and effort in an organization. Moreover, the sharing of knowledge between employees enables enhanced working experience and enhances problem-solving skills, which increases the satisfaction of accountants at work (Raisi \& Forutan, 2017).

\section{CONCLUSION}

Based on the literature review being conducted about the organizations and various factors influencing the professional's job satisfaction, the researcher had identified several areas in the literature, which can be further explored. There are many types of research being conducted about job satisfaction, but there is limited research being conducted to explore the professional's job satisfaction. Factors like the impact of clan culture, adhocracy, and knowledge, which might significantly influence the professional's job satisfaction, can be further explored. Therefore, this research plan to further study and gather more comprehensive data on the interrelationships between clan, adhocracy, market, and hierarchy culture, which will affect professional's job satisfaction to stay in the firm.

\section{REFERENCES}

1. Ahamed, M. \& Mahmood, R (2015). Impact of Organizational culture on job satisfaction: A study on Banglalion communication Itd, Bangladesh. European Journal of Business and Management, 7(10), 160-174.

2. Aldhuwaihi, A., \& Shee, $H$ (2015). Organizational culture and employee turnover in Saudi Arabian banks. International Journal of Management, 4(4), 1-19.

3. Ashraf, G., \& Rezaie, M. H (2015). Organization culture: A predictor of faculty members' job satisfaction. British Journal of Education, 3(8), 1-9.

4. Aziri, B (2011). Job satisfaction: A literature review. Management Research and Practice, 3(4), 77-86.

5. Badawy, T. A. E., Kamel, M. M., \& Magdy, M. M (2016). Exploring the relationship between organizational culture, job satisfaction, and organizational citizenship behavior. International Journal of Human Resource Studies, 6(4). doi:10.5296/ijhrs.v6i4.9939r

6. Cameron, $\mathrm{K}$ (2011). An introduction to the competing values framework. Haworth, 2-4.

7. Cameron, K. S., \& Quinn, R. E (2006). Diagnosing and changing organizational culture: Based on the competing values framework. The Jossey-Bass Business \& Management Series.

8. Chan, A (1997). The corporate culture of a clan organization. Management Decision, 35(2), 97-99. doi:10.1108/00251749710160232

9. Chan, T. J., Wong, Z. Y. \& Wok, S (2017). Predicting factors of job satisfaction through organizational culture: A case of Malaysian private learning institution. Malaysian Journal of Communication, 33(3), 37-54.

10. Chatterjee, A., Pereira, A., \& Bates, R (2018). Impact of individual perception of organizational culture on the learning transfer environment. International Journal of Training and Development, 22(1), 15-33. doi:10.1111/ijtd.12116

11. Chipunza, C., \& Malo, B (2017). Organizational culture and job satisfaction among academic professionals at a South African university of technology. Problems and Perspectives in Management, 15(2). doi:10.21511/ppm.15(2).2017.14

12. Chow, C. W., Ho, J. L., \& Vera-Munoz, S. C (2008). Exploring the extent and determinants of knowledge sharing in audit engagements. Asia-Pacific Journal of Accounting \& Economics, 15, 141-160.

13. Dadgar, H., Barahoue, F., Mohammadi, M., Ebrahimi, M., \& Ganjali, A (2013). The relationship between organizational culture, job satisfaction, organizational commitment, and intention to stay of health personnel of Zahedan University of medical sciences. World Applied Sciences Journal, 21(8), 1220-1228. doi:10.5829/idosi.wasj.2013.21.8.108 
14. Din, H. F., \& Ghetany, H. E (2016). The relationship between organizational culture and job satisfaction: An international perspective. Proceedings of the European Conference on Management, Leadership \& Governance, 101-109.

15. Dirisu, J., Worlu, R., Osibanjo, A., Salau, O., Borishade, T., Meninwa, S., \& Atolagbe, T (2018). An integrated dataset on organizational culture, job satisfaction, and performance in the hospitality industry. Data in Brief, 19, 317-321. doi: 10.1016/j.dib.2018.04.137

16. Fair, C. \& Wright, H (2016). Wellbeing and the importance of workplace culture. United Kingdom: Great place to work. Retrieved from http://www.greatplacetowork.co.uk/storage/Publications/wellbeing_and_culture_final_011 216.pdf

17. Felipe, C. M., Roldan, J. L., \& Leal-Rodriguez, A. L (2017). Impact of organizational culture values on organizational agility. MDPI-Sustainability, 9, 1-23. doi:10.3390/su9122354

18. Goryachev, A (2018). 5 Proven ways to create a lasting legacy of employee innovation. HR Technologist. Retrieved from https://www.hrtechnologist.com/articles/culture/5proven-ways-to-create-a lasting-legacy-of-employee-innovation

19. Hui, T. Y., Yep, C., Shiuh, C. Y., Voon, O. S., Hu, T Y., (2019). Organizational Culture As An Influencer To Job Satisfaction In Accounting Firms, Malaysia. Research Project. Universiti Tunku Abdul Rahman, Malaysia.

20. Hermanson, D. R., Houston, R. W., Stefaniak, C. M., \& Wilkins, A. M (2016). The work environment in large audit firms: Current perceptions and possible improvements. Current Issues in Auditing, 10(2), 38-61. doi:10.2308/ciia51484

21. Irfan, S., \& Marzuki, N. A (2018). The moderating effects of organizational culture on the relationship between work motivation and work commitment of university academic staff. International Journal of Learning and Development, 8(1), 137-155. doi:10.5296/ijld.v8i1.12484

22. Janjua, Q. R., Ahmad, H. M., \& Afzal, A (2014). The impact of internal marketing and the moderating role of organizational culture on nurse job satisfaction. Journal of Business \& Economics, 6(2), 203-244.

23. Janus, S. S (2016). Becoming a knowledge-sharing organization. International Bank for Reconstruction and Development. doi:10.1596/9781-4648-0943-9

24. Karimi, Y., \& Kadir, S. L. S. A (2012). The impact of organizational culture on the implementation of TQM: Empirical study in the Iranian oil company. American Journal of Industrial and Business Management, 2, 205-216. doi:10.4236/ajibm.2012.24027

25. Khurshid, F., \& Awan, M. U (2017). Service quality and organizational culture as predictors of faculty job satisfaction. Pakistan Business Review, July 2017, 499-517.

26. Kianto, A., Vanhala, M., \& Heilmann, P (2016). The impact of knowledge management on job satisfaction. Journal of Knowledge Management, 20(4), 621-636. doi:10.1108/JKM10-2015-0398

27. King, W. R., \& Marks, Jr, P. V (2008). Motivating knowledge sharing through a knowledge management system. Omega The International Journal of Management Science, 36, 131-146. doi:10.1016/j.omega.2005.10.006

28. Koutroumanis, D. A., Alexakis, G., \& Dastoor, B. R (2015). The influence organizational culture has on commitment in the restaurant industry. Small Business Institute Journal, 11(2), 27- 40.

29. Kuzu, O. H., \& Ozilhan, D (2014). The effect of employee relationships and knowledge sharing on employees' performance: empirical research on the service industry. Social and Behavioral Sciences, 109, 1370-1374. doi:10.1016/j.sbspro.2013.12.639

30. Kwakye, E. A (2018). Organizational culture and employee turnover: Evidence from Ghana. British Journal of Economic Management and Trade, 21(2), 1-11. doi:10.9734/JEMT/2018/39062

31. Lund, D. B (2003). Organizational culture and job satisfaction. Journal of Business \& Industrial Marketing, 18(3), 219-236. doi:10.1108/0885862031047313.

32. Martínez-León, I. M., Olmedo-Cifuentes, I., \& Ramón-Llorens, M. C (2018). Work, personal, and cultural factors in engineers' management of their career satisfaction. 
Journal of Engineering and Technology Management, 47, 22-36. doi:10.1016/j.jengtecman.2017.12.002

33. Marouf, L (2015). Employee perception of the knowledge sharing culture in Kuwaiti companies: Effect of demographic characteristics. Library and Information Science Research e-journal, 25(2), 103-118.

34. Mayhew, R (2017, September 26). The impact of dissatisfied employees. Retrieved from https://bizfluent.com/info-7749196-impact-dissatisfied-employees.html

35. Meng, J. \& Berger, B. K (2019). The impact of organizational culture and leadership performance on PR professionals' job satisfaction: Testing the common mediating effects of engagement and trust. Public Relations Review, 45(1), 64-75. doi:10.1016/j.pubrev.2018.11.002

36. Monga, O. P., Monga, A., Mahajan, V., \& Monga, A (2015). Organizational culture, stress, and commitment: A study of managers of the pharmaceutical industry in Himachal Pradesh. Open Access Library Journal, 2, 1-11.

37. Moyes, G. D., \& Reed, T. C (2008). An empirical analysis of factors influencing the level of job satisfaction of Caucasian and Hispanic accounting professionals. International Business \& Economics Research Journal, 7(10), 21-42.

38. Ogbeibu, S., Senadjki, A., \& Gaskin, J (2018). The moderating effect of benevolence on the impact of organizational culture on employee creativity. Journal of Business Research, 90, 334-346. doi:10.1016/j.jbusres.2018.05.032

39. Oz, M., Kaya, F., \& Ciftci, I (2015). Evaluating the organizational culture types of 5-star hotels in Istanbul in terms of the Cameron \& Quinn competing values model. Journal of Yasar University, 10(40).

40. Ozturk, A. B., Hancer, M., \& Wang, Y. C (2014). Interpersonal trust, organizational culture, and turnover intention in hotels: A cross-level perspective. Tourism Analysis, 19(2), 139-150. doi:10.3727/108354214X13963557455522

41. Panagiotis, M., Alexandros, S., \& George, P (2014). Organizational culture and motivation in the public sector. The case of the city of Zografou. Procedia Economics and Finance, 14, 415-424. doi:10.1016/S2212-5671(14)00730-8

42. Pichler, F. \& Wallace, C (2009). What are the reasons for differences in job satisfaction across Europe? Individual, compositional, and institutional explanations. European Sociological Review, 25(5), 535-549.

43. Pinho, J. C., Rodrigues, A. P., \& Dibb, S (2014). The role of corporate culture, market orientation, and organizational commitment to organizational performance. Journal of Management Development, 33(4), 374-398. doi:10.1108/JMD-03-2013-0036

44. Quinn, R. E. \& Cameron, K (1983). Organizational life cycles and shifting criteria of effectiveness: Some preliminary evidence. Management Science, 29(1), 33-51.

45. Raisi, E., \& Forutan, M (2017). Study of the relationship between knowledge sharing culture and job satisfaction. International Academic Journal of Economics,4(3), 29-36.

46. Rakowska, A., Valdes-Conca, J., \& Juana Espinosa, S (2018). Affecting factors of public employees' organizational commitment. International Journal of Synergy and Research, 3, 5-26.

47. Rastegar, A. A., \& Aghayan, S (2012). Impacts of organizational culture on organizational commitment. Journal of Human Resource Management, 2(2), 1-13.

48. Ravari, A., Mirzaei, T., Kazemi, M., \& Jamalizadeh, A (2012). Job Satisfaction as a multidimensional concept: A systematic review study. Journal of Occupational Health and Epidemiology (JOHE), 1(2), 95-102.

49. Rehman, M., Mahmood, A. K., Salleh, R., \& Amin, A (2014). Job satisfaction and knowledge sharing among computer and information science faculty members: A case of Malaysian universities. Research Journal of Applied Sciences, Engineering, and Technology, 7(4), 839-848. doi:10.19026/rjaset.7.326

50. Reis, G., Trullen, J., \& Storey, J (2016). Perceived organizational culture and engagement: The mediating role of authenticity. Journal of Managerial Psychology, 31(6), 1091-1105. doi:10.1108/JMP-05-2015-0178 
51. Saeed, M. S (2016). The impact of job satisfaction and knowledge sharing on employee performance. Journal of Resources Development and Management, 21, 16-23.

52. Samuel, O. B (2015). The effects of organizational culture and stress on organizational employee commitment. Management, 5(3), 96-106. doi:10.5923/j.mm.20150503.03

53. Santos, C. R., Rivera, M. A., Pinto, L., \& Oliveira, L (2018). The relationship between organizational culture, organizational commitment, and job satisfaction. Rebrae, 11(2), 201-215.

54. Shurbagi, A. M (2015). The effect of organizational culture on the relationship between job satisfaction and organizational commitment. International Journal of Humanities and Management Sciences (IJHMS), 3(1), 19-25.

55. Shurbagi, A. M., \& Zahari, I. B (2014). The mediating effect of organizational commitment on the relationship between job satisfaction and organizational culture. International Journal of Business Administration, 5(6), 24-37. doi:10.5430/ijba.v5n6p24

56. Sinaga, R. I., Siburian, P., \& Lubis, W (2018). The effect of organizational culture, job satisfaction, and achievement motivation on teacher work commitments in junior high school of Teladan Timur in Medan. International Journal of Scientific Research in Science, Engineering and Technology, 4(11). doi:10.32628/IJSRSET21841121

57. Soltanizadeh, N., \& Sanaei, N (2015). Effects of organizational culture on faculty members' job satisfaction. Journal of Paramedical Sciences, 6(1).

58. Tarigh, M. P., \& Nezhad, F. R (2016). The impact of job satisfaction and work environment-friendly on services innovation with the mediator role of knowledge sharing in companies under the supervision of parstousheh in Gilan province. Bulletin de la Societe Royale des Sciences de Liege, 85, 1017-1025.

59. Taskiran, E., Cetin, C., Özdemirci, A., Aksu, B., \& İstoriti, M (2017). The Effect of the harmony between organizational culture and values on job satisfaction. International Business Research, 10(5), 133-147.

60. The 2017 Deloitte millennial survey (2017). Retrieved from https://www2.deloitte.com/content/dam/Deloitte/au/Documents/about- deloitte/deloitte-auabout-millennial-survey-2017-030217.pdf

61. Yaoprukchai, S., \& Kardkarnklai, U (2014). Organizational culture: The perspectives of new hires and existing employees of a pharmaceutical company in Thailand. Asian Social Science, 10(14). doi:10.5539/ass.v10n14p224

62. $\mathrm{Yu}, \mathrm{T}$., \& Wu, N (2009). A review of a study on the competing values framework. International Journal of Business and Management, 4(7), 37-42.

63. Zahid, M., Shaikh, T. \& Zehra, S. Z (2017). Impact of organizational culture on the Pakistani hotel's workforce's job satisfaction: Qualitative report. International Journal of Applied Business and Management Studies, 2(1), 37-45.

64. Zeleke, B., \& Beyene, H (2015). The link between organizational culture and instructor's job satisfaction at St. Mary's university college in Adidas baba. The Ethiopian Journal of Education, 35(1), 1-44.

65. Zotorvie, J. S. T., Kudo, M. B., \& Adade, T. C (2017). A survey of factors that influence the level of job satisfaction and turnover intention of professional accountants in Ghana. International Journal of Academic Research in Business and Social Sciences, 7(10), 41 56. doi:10.6007/IJARBSS/v7- i10/3357. 